\title{
Women Editors and the Rise of the Illustrated Fashion Press in the Nineteenth Century
}

\author{
Marianne Van Remoortel \\ Department of Literary Studies, Ghent University, Ghent, Belgium
}

\section{Introduction}

In the second half of the nineteenth century, a new type of magazine emerged in Europe and the United States. Fashion-a staple of up-market women's periodicals since the late-eighteenth century-was no longer the prerogative of the elite press. Thanks to technological advances in printing, communication, and transportation, it became a core ingredient of a growing number of affordable, lavishly illustrated women's and family magazines. These publications not only offered increasingly sophisticated visualizations and descriptions of the latest fashions, they also contained more detailed and user-friendly patterns with instructions enabling readers to dress themselves and their families fashionably on a modest budget. This shift away from leisure-class luxury towards a more practical, hands-on approach was a key moment in the history of fashion and in women's history. The new magazines actively targeted women as consumers and practitioners of style, granting them an unprecedented sense of control over their public identities. Femininity became, quite literally, "makeable."

Credit for this shift tends to go to a few big-name publishers, such as Adolphe Goubaud and the Didot brothers in Paris, Louis Schäfer in Berlin, and Samuel Beeton in London. These men have gone down in history as the trailblazers of the illustrated fashion press. They are generally seen as clever entrepreneurs who capitalized on the latest technological developments and joined forces on an international scale as they negotiated deals to exchange textual and visual materials among their respective magazines. Kate Nelson Best counts Goubaud among the "most powerful 
new press magnates" (106) of the Second French Empire, pointing out that Le Moniteur de la mode (1843-1913) had ten foreign editions by 1869, in English, Russian, Spanish, and other languages. Beeton is described in the Oxford Dictionary of National Biography as a "pioneer of popular print," an epithet due in no small measure to his 1860 deal with Goubaud to import fashion plates from $L e$ Moniteur into the Englishwoman's Domestic Magazine (1852-79). Schäfer, for his part, gained fame for establishing Der Bazar (1855-1936) as a "Weltblatt" (global journal) with a "Weltruf" ("Zum Beginn" 1) (global reputation). ${ }^{1}$ Already in 1863, it boasted a circulation of more than 200,000 copies: 105,000 in German, 50,000 in English, 32,000 in French, and 15,000 in Spanish ("Der Bazar" 1863 n.p.). When more versions in Dutch, English (US), Russian, Italian, Hungarian, and Czech pushed figures to "mehr als eine halbe Million" (over half a million), it proudly claimed to be "die verbreitetste Zeitung der Welt" ("Der Bazar" 1873 241) (the most widespread journal in the world).

If circulation figures are notoriously unreliable indicators of readership, the use of the word "Ausgabe" ("Der Bazar" 1863 n.p.) (edition) is more subtly deceptive. Scholars of the Victorian press, for example, may be surprised to learn that the periodical listed as the English "edition" is the Englishwoman's Domestic Magazine. Samuel Beeton touted his connections with Paris, but kept silent about importing material from Germany, and would never have advertised his magazine as a satellite to any foreign title. Similarly, the French edition, La Mode illustrée (1860-1937), established a strong reputation as the flagship journal of the Didot publishing house without ever hinting at its indebtedness to Der Bazar. In the fast-changing fashion magazine market, competition was rife among publishers as to whose journal was the most innovative, the most influential, and the most prestigious.

This article looks at the development of the illustrated fashion press from a different perspective. It goes beyond the level of the publishers, beyond their legal power to sign contracts 
and ability to wield the latest technologies, in order to demonstrate the importance of studying these magazines as cultural products. More particularly, I aim to show that Der Bazar's so-called "editions" were more than foreign-language duplicates of the original. Illustrations were selected, imported, and incorporated in different ways and under different conditions; texts were added, omitted, translated, and adapted from and by Der Bazar as well as independently, among the various "editions." Setting up such a complex series of transnational exchange practices required specific skills, such as advanced language proficiencies, keen insight into the demands of the women's magazine market at home, and cultural affinity with the fashion press abroad. I argue that these skills were not so much to be found in the (male) publishers of the magazines but rather in the editors, most of whom were highly educated, multilingual women.

\section{The women behind Der Bazar}

Although Der Bazar made Louis Schäfer's name in the publishing world, the idea for the journal was not his, nor did he personally have the resources to finance it. It was the successful female playwright and novelist Antonie von Cosmar (1806-70) who approached him with the idea in the early 1850s, and the funds were provided by Schäfer's wife. Von Cosmar had over twenty years of experience in fashion journalism, having worked on the Berliner Modenspiegel (1832-49) as a translator of French fashion news and taken over the editorship from her husband Alexander von Cosmar after his death in 1842. Following a dispute with colleagues whom she felt had betrayed her trust, she decided to carry out her long-cherished plan of establishing a magazine for women "bei deren Redaction ich jede männliche Stüße entbehren konnte" (qtd. in Schreve 348) (that I could edit without any male support). After a first failed attempt under the title of Berliner Modenund Musterzeitung (1850), she contacted Schäfer, "und fand in [ihm] einen Verleger für meinem ihm mitgeteilten Plan, wie ich ihn mir nicht besser wünschen konnte" (348) (and found in [him] as 
good a publisher for this plan as I could have wished for). Der Bazar: Technische Muster-Zeitung für Frauen was launched on 10 December 1854 as a fortnightly consisting of sixteen doublecolumn pages of fiction, essays, poetry, needlework, fashion, and supplementary patterns. At this point, Schäfer was little more than a "bookseller in Berlin," too obscure to be named in the daily press as the founder of the new magazine. Von Cosmar, by contrast, was explicitly announced to have taken up the position of editor:

Ein Buchhändler in Berlin hat so eben eine neue Muster-Zeitung für Frauen (unter dem Titel “Der Bazar") ins Leben gerufen, welche ein wahres Omnibus alles Dessen, was unsere Damen interessirt, gennant zu werden verdient.-Nicht allein, daß für die Redaktion vorzügliche Kräfte gewonnen sind (das Hauptblatt redigirt die unter dem Namen A. Cosmar als Schriftstellerin bekannte Frau Dr. Klein, und das Feuilleton der bisherige Redakteur der “Jahreszeiten” Feodor Wehl). (“Ein Buchhändler” 1220)

(A bookseller in Berlin has just founded a new dressmaking journal for women [entitled "Der Bazar"], which deserves to be called a true omnibus of all that interests our ladies.Not only because excellent talents have been recruited for the editing [The main magazine is edited by Frau Dr. Klein, who is known as a writer under the name of A. Cosmar, and the feuilleton by the former editor of the "Jahreszeiten" Feodor Wehl].)

According to von Cosmar, Schäfer "scheute weder Mühe noch Kosten, das Unternehmen ... ins leben zu rufen" (348) (spared neither trouble nor expense to set up the enterprise). In reality, it was his wife who provided the capital needed to establish the magazine ("Herr Abington" 2). Margarethe Schäfer (c.1821-94), née Voit, was a descendant of a wealthy Bavarian family of entrepreneurs and organ builders. While von Cosmar initiated the new journal and lent it authority, she made sure that it was financially viable. She also co-edited it alongside von Cosmar and tested the incoming dress and embroidery patterns ("14." 3). One newspaper later commented that Der 
Bazar owed its great success in no small part to her "sorgfältigen Arbeit" ("14." 3) (meticulous work), pointing out that the journal brought Schäfer "nicht nur Titel und Würden, sondern auch ein Millionen-Vermögen" (not only title and prestige but also a multi-million fortune), and that he added her name "mit gutem Recht" (“14." 3) (rightly) to his when he was raised to the peerage as von Schaeffer-Voit in 1865.

For all that Der Bazar laid “den Grund zu seiner späteren Verbreitung” (Brümmer 443) (the foundation for its later expansion) under von Cosmar's direction, her editorship was short-lived. While the fledgling journal inaugurated Louis and Margarethe Schäfer's partnership as a publishing power couple, she gave up her post after only three months. In a letter to the phrenologist Gustav Schreve she explained that Schäfer considered her work done when circulation rocketed to 10,000 copies after the first quarter: "Ich war mir zu wohl bewusst, was ich wollte und bezweckte, und mochte mich zu seiner Arbeitsmaschine erniedrigen lassen; Herr Schäfer konnte dagegen eine selbstständige Person meiner Art für seine Zwecke nicht brauchen.” (348-49) (I was too well aware of what I wanted and aimed for, and gladly submitted myself to his labor machine. Mr Schäfer, on the other hand, for his own aims had no need for an independent person of my kind.) Even if von Cosmar was no longer involved at editorial level, the signatures "A. v. C." and "K. v. C." under the fashion columns for $1856-57$ indicate that she remained affiliated as contributor for some time. ${ }^{2}$

On 1 December 1856, Der Bazar announced that it was about to undergo a restyling. Due to space constraints, the magazine had its shortcomings, a lengthy notice admitted, but these would be solved by an increase in format and frequency ("An unsere Abonnentinnen" 339). From 1 January 1857, Der Bazar appeared as a folio weekly under a new masthead decorated with elegant floral motifs and depicting a woman reading what appears to be a copy of the journal itself inside the capital letter D of the title (Figure 1). Now subtitled Illustrirte Damen-Zeitung, it started alternating general issues with issues devoted almost exclusively to fashion and needlework. While 
the weekly frequency and general issues allowed it to keep pace with the expanding family magazine market dominated by Die Gartenlaube (1853-1937), the fashion numbers took Der Bazar, and fashion journalism in general, in a new direction. For the French fashion press and the many periodicals following in its lead, steel-engraved fashion plates had been the way forward since the 1820 s. These plates were expensive to produce-they had to be printed separately and painstakingly colored in-evoking the exclusivity and refinement that characterized the fashion discourse of the time. Der Bazar too had included French fashion plates in its early issues. They were copied with some modifications from Le Moniteur de la mode, probably without Goubaud's permission, their quality never equalling that of the originals. Apart from the fashion plates, these early issues made sparing use of visual material (Figure 2). Dress illustrations were typically grouped and printed on supplement sheets, with numbers referring readers to the instructions in the issue.

As part of the 1857 make-over, Der Bazar abandoned steel engraving altogether and opted for cheaper wood engraving instead. Wood was less up-market, but also more versatile, enabling the journal to bring fashion to its readers in a radically new way. As the notice explained:

Alle kleinen Beilagen unserer Zeitung fallen von jetzt an fort, sämmtliche Abbildungen werden in den Text gedruckt, und soll es unsere Sorge sein, die Nachahmung der Muster den geehrten Abonnentinnen dadurch zu erleichtern, dass die Erklärung stets unmittelbar unter der abbildung zu finden sei.

Schnittmuster werden allmonatlich ein Mal auf einem grossen Bogen der Zeitung als Supplement beigelegt.

Durch das Wegfallen der kleinen, leicht verlierbaren Beilagen ist der "Bazar" jetzt mehr als sonst geeignet, eingebunden, und so in fester Gestalt ein Hausschatz zu werden, welcher 
lange Jahre hindurch seinen Besitzerinnen Freude, Nutzen und Belehrung gewährt. (“An unsere Abonnentinnen” 339)

(As of now, all small supplements to our journal are dropped, all images are printed in the text, and it will be our concern to facilitate the imitation of the patterns for our esteemed subscribers in that the explanation will always be located immediately below the image.

Dress patterns will be published once a month as a supplement on a large sheet of paper.

By discarding the small, easily losable supplements, the "Bazar" is now more than ever fit, when bound and therefore in firmer shape, to become a domestic treasure, which for many years will grant its owners pleasure, utility, and instruction.)

The switch to wood engraving allowed Der Bazar to integrate image and text in ever new constellations. Rather than presenting static images of fashionably dressed women on separate sheets, the fashion issues showcased gowns, bodices, and mantles from different angles, including side and back views. Hats and hairstyles were arranged in impressive line-ups; models' poses varied from full-body to three-quarter to close-up. Text descriptions flowed in between the illustrations, making the garments on display almost tangible (Figure 3). From there, it was only a small step to the dressmaking patterns in the supplements. While older French publications such as Journal des demoiselles (1833-1922) and Petit courrier des dames (1821-68) had included pullout pattern sheets for the latest fashions since the 1840s (Emery 21-2), the new folio-size Bazar was the first to connect high fashion with such visual prominence to home dressmaking. In doing so, it was also building on the legacy of the Journal des Luxus und der Moden (1786-1827), which is generally regarded as the first German-language fashion magazine. Journal des Luxus und der Moden did not offer patterns alongside its fashion plates, but, as Caryl Clark has argued, it did take crucial steps towards "conventionalizing female fashion ... for mothers and housewives of all ages" by "aligning" fashion images "with a discourse that downplayed aristocratic masquerading" and 
appealed more directly to the emerging middle classes (157-58). Almost overnight, Der Bazar had transformed from an unremarkable women's magazine taking its cue from Paris to one that singlehandedly put fashion within readers' reach. If most middle-class women could only dream of buying custom-made clothes, they did have the needle skills and, increasingly, the affordable home sewing machine to produce their own.

In a piece written for the seventieth anniversary of Der Bazar in 1924, fashion historian Max von Boehn described the decision to use wood engraving to bring together "Text und Bilder in den engsten Zusammenhang brachte" (text and images in the closest connection) as "eine glückliche Idee" (n.p.) (a happy idea). Without further historical evidence we can only speculate as to exactly whose "happy idea" it was, but at least one telling detail points in the direction of the editorial department. In the early years of Der Bazar, rather than giving proper credit to its editors, Schäfer tended to use standard formulations that subsumed their work under his own. Thus, both the publishing and editing were credited to "L. Schäfer" in 1856-58; from 1859, the journal was edited "unter Verantwortlichkeit der Verlagsbuchhandlung" (under the responsibility of the publisher-bookseller). The notice announcing the revamped Bazar, by contrast, was signed "Die Gesammt-Redaction" (The Editorial Staff), suggesting close editorial involvement in the redesign.

The signature also implies the continued participation of women, for in the years following von Cosmar's departure, several joined Der Bazar as editors. Indeed, by 1861, the journal had gained local notoriety for having an all-women editorial staff. In an article on female industry, the Regensburger Zeitung commented: "Vier Frauen leiten die ganze Redaction.... Zwei von ihnen besorgen das literarische Fach; zwei anderen die Handarbeiten und Schnitte" ("Frauen-Industrie" 4) (Four women run the entire editorial office.... Two manage the literary department; two others the needlework and dress patterns). All were paid employees. The head of the fashion staff had an annual income of 700 thaler and a pension for life; the others received 400 thaler with some benefits 
("Frauen-Industrie" 4). ${ }^{3}$ The article does not give their names, but on the basis of various other sources, all can be identified with reasonable certainty. Agnes Kähler (1819-95) and poet and novelist Marie Harrer (1819-70) joined the editorial staff in 1856. Kähler wrote needlework instructions and translated English material under her own name and as "Agnes K." Harrer served as editor of the literary section, to which she also contributed some of her own work (Morgenstern 358). Her name occasionally appears under the correspondence column. Frieda Gestefeld (184096) was "von dem Wunsch getrieben, eine selbstständige Stellung zu erringen” ("Freifrau” 137) (driven by the desire to gain an independent position) when she left her parents' house in Hannover at age twenty to work as a fashion editor for Der Bazar. She was "eine geschätzte Kraft" (137) (a valued force) there for five years, until she married her colleague Franz Lipperheide and went on to establish Die Modenwelt (1865-1942) with him. They were followed by Kähler, who became a collaborator on the new journal (Kähler 67). It appears that Kähler and Gestefeld had been working closely together on Der Bazar's fashion issues in the early 1860s: the numerous dressmaking instructions signed "K." and "G." are probably theirs. Author, translator, and later women's rights advocate Jenny Hirsch (1829-1902) was offered a well-paid editorial job on Der Bazar in 1860, after submitting some of her writings. Together with Harrer, she vetted the literary submissions and, since she was well-versed in French and English, probably also selected foreign fiction for translation. She held the post until 1864 (Morgenstern 218).

In the second half of the $1860 \mathrm{~s}$, the thematic division in the editorial staff became a gendered one. The literary issues were overseen by a succession of named male editors, including Julius Rodenberg (1865), Karl August von Heigel (1868), and Ludwig Lenz (1880). The fashion numbers continued to go uncredited apart from the 1867-70 ones edited by Louise Fabé, but appear to have remained under female editorship. ${ }^{4}$ In December 1868, Der Bazar published a double-page wood engraving of its production process reflecting this new divide (Figure 4). Arranged in a circle 
are various scenes depicting the pattern draughtsmen, stereotypers, type founders, compositors, paper wetters, printers, shippers, and literary editors-all men—carrying out their jobs. In the middle, a large illustration shows the fashion editorial office as an exclusively female space. In an airy, well-decorated room with high ceilings, two women are sitting behind elegant desks, while five others are inspecting fabrics or engaging in conversation. According to a long accompanying piece, one was the editor-in-chief, the others were working under her supervision. In addition to touching on some of the fashion issues' "tiefste Redactionsgeheimnisse" ("Vom 'Bazar"” 381) (deepest editorial secrets) - the questions of what to publish, when to publish in order stay ahead of the seasons, and how to avoid repetition — the article describes the hustle and bustle of a typical working day:

Die Zeichner, Holzschneider, Graveure und Formstecher holen sich von der Chefredactrice Aufträge und Instructionen, die Modistinnen legen die nach Vorschrift der Redaction gefertigten Schnittmuster vor, und junge Damen bringen die nach Angabe ausgeführten Handarbeiten. In diesem Zimmer wird corrigirt, im anstossenden debattirt, und in einem dritten arbeitet man an der Beschreibung einer neuen "Bluse mit Soutachebesatz". Aus Paris kommt eine Depesche, dass Monsieur A. oder B. vor Ablauf der Woche das Modebild nicht fertig zeichnen könne, und aus der Thür, welche zur "Belletristik" führt, fragt eine Männerstimme: ob denn Frau Veronica von G. noch nicht den Modebericht gesendet habe? ("Vom 'Bazar”" 381)

(The draughtsmen, wood-cutters, engravers, and block-cutters receive their orders and instructions from the editor-in-chief, the modistes present the patterns prepared as stipulated by the editorial staff, and young ladies bring the needlework articles executed according to specification. In this room corrections are made, in the adjoining one discussions are held, and in the third one the description of a new "Blouse with Soutache Trimmings" is underway. From Paris comes a telegram that Monsieur A. or B. cannot finish the fashion 
drawing before the end of the week, and outside the door, which leads to "Literature," a man's voice asks if Frau Veronica von G. has not yet sent her fashion report.)

Visually as well as in words, Der Bazar placed the fashion department at the heart of the enterprise, yet the women overseeing the fashion issues received little recognition for their work in the pages of the journal. One reason for their anonymity may be that Schäfer wanted credit to go to the publishing house as a whole. The fashion issues, after all, were rapidly becoming its most successful export product.

\section{Adopting and adapting the model}

The revamped Bazar became a source of inspiration for women's periodicals across Europe and beyond. The 1860s saw the birth of at least eight magazines indebted to it in some way or another, and several existing ones started borrowing material. Depending on the nature of their relationship with Schäfer's publishing house, which is not always straightforward to determine and could change over time, these publications generally fell into three types: those relying on unauthorized reuse, those with contracts to borrow some material, and those whose contracts stipulated a visual layout almost completely identical to Der Bazar's.

As early as 1859 , the British Ladies' Treasury (1857-95) took advantage of the lack of international copyright protection, which remained unregulated until the Berne Convention of 1886, to copy fashion illustrations from Der Bazar sporadically, carefully omitting the signature of the Leipzig wood-engraving firm that had produced them. ${ }^{5}$ The Dutch Gracieuse (1862-1936), the Philadelphia-based Lady's Friend (1864-73), and possibly also the short-lived Polish Bazar (1865-66) and Danish Nordisk Mønster-Tidende (1874-1952) relied more extensively on pirated Bazar fashion material. The latter two evidently reproduced illustrations from Der Bazar, but it is unclear if they were doing so with Schäfer's permission. The German sources I consulted did not 
yield any evidence of a formal connection, but that does not mean that there was no such arrangement at some point.

Among the publications that Der Bazar labelled as "editions" quite a few had contracts to import clichés—-metal casts of the original wood engravings—-from which the illustrations could be printed locally. Because clichés were made for each individual image, these magazines had considerable freedom in how they selected and implemented the material. The Englishwoman's Domestic Magazine included illustrations from Der Bazar in a one-shilling fashion supplement; later it also issued them on large pattern sheets entitled (somewhat ironically given their German origins) "Parisian Patterns." The French La Mode illustrée, Spanish La Moda elegante (18421927), and Italian La Novità (1864-1943) all emulated the Bazar fashion issues throughout their pages, including the lavish masthead and catalogue-like layout, while also providing a significant amount of content of their own.

The magazines that came closest to being actual editions of Der Bazar were those contracted to receive full-page electrotypes or pre-printed pages with the illustrations only, ready to be filled up with translations based on the German proofs and original contributions in the local language. The only marked difference was in the front page: each publication was supplied with its own version of the masthead. The Gracieuse became the first in this group in 1864, after its unauthorized copying was exposed by Schäfer. Other examples, for at least part of their runs, include Novyi russkii bazar (1867-98), published in Saint Petersburg, and the Austro-Hungarian Magyar Bazár (1866-1904). Even within this category, variations occurred. The Czech Květy (1865-72) and Světozor (1872-1899), for instance, issued their Bazar as a fashion supplement. The New York Harper's Bazar (later Harper's Bazaar; 1867-), while probably the best known of the spin-offs, copied only a portion of the German original. Issues donned the familiar masthead and 
typically consisted of three to four pages based on Bazar electrotypes, complemented with about a dozen filled with other, mainly textual material.

Many of these magazines had female editors who were instrumental in establishing the connections with Berlin. Rather than Der Bazar reaching out to them, as the term "Ausgabe" (edition) used in the German press would suggest, they reached out to Der Bazar as a source and model for their own publications. Some did so in the context of a husband-and-wife collaborative partnership in which their creative talents could thrive. Like Margarethe Schäfer, Isabella Beeton (1836-65) of the Englishwoman's Domestic Magazine, Laura Aller (1849-1917) of the Nordisk Mønster-Tidende, and Sarah Peterson (1829-91) of the Lady's Friend worked alongside publisher husbands who facilitated access to technological resources and could enter into contracts when legal barriers prevented women from doing so. Others, including the Dutch sisters Susanna Maria (1818-1882) and Johanna Weeveringh (1820-1887) of the Gracieuse, La Mode illustrée's Emmeline Raymond (1828-1902), and Harper's Bazar's Mary Louise Booth (1831-89) were unmarried and recruited as waged employees through publishers' professional networks. ${ }^{6}$

Although their specific personal and professional backgrounds varied, all brought advanced language skills and cross-cultural affinities to the task. Laura Aller was home-schooled in English, French, and particularly German, which had been as essential to her spice merchant father's business as it was to her early career in needlework instruction. Isabella Beeton, Mary Louise Booth, and Emmeline Raymond were translators, like so many of the original Bazar editors. Beeton was taught French and German at boarding school in Heidelberg, and translated French fiction for the Englishwoman's Domestic Magazine. Kathryn Hughes' 2006 biography reveals that she played a key role in negotiating her husband's 1860 contract with Goubaud (255-61); I believe that she was most likely also involved in the dealings with Berlin that materialized in a "Fashions and Needlework" supplement from 1864 onwards. According to the French newspaper Le Figaro, 
Emmeline Raymond was caught up in "une rare complication de patries" (Montclair 18) (a rare entanglement of homelands). She was born in Chernivtsi, then part of the Austro-Hungarian Empire, to a Belgian father serving as officer in the Austrian army and a French mother who ran a girls' boarding school in what would later become Romania (Montclair 18; Renken-Deshayes 62). Her published works before La Mode illustrée include translations from the German, the language to which she had been first exposed as a child. Mary Louise Booth was a grand-daughter of a French Revolutionary refugee and a prolific translator of French literature before she became editor of Harper's Bazar. She also "read and spoke easily ... Italian, German and Spanish"—in short, her "equipment for the profession was of the most complete" (Spofford 232).

High proficiency in multiple languages was a crucial skill in fashion journalism. Many editors appear to have been given carte blanche by their publishers or at least taken a particularly hands-on approach to editing. As editor of the Nordisk Mønster Tidende published by her husband Carl Aller, Laura Aller "evnede lige præcis at finde frem til, hvad et af datidens modeblade skulle indeholde. Hun forstod at knytte personer til sig, der kunne bistå med og opfange de ting, der interesserede kvinder" (Grølsted 18) (was able to find out exactly what a contemporary fashion magazine should contain. She knew how to associate with people who could assist in finding the things that interested women). Emmeline Raymond was a contributor to the Journal des demoiselles when its editor Jeanne-Justine Fouqueau de Pussy suggested her name to Ambroise Didot in 1859 (Montclair 18). Although she was a little-known writer at the time, she was contracted to establish a new women's magazine for the French market without specific instructions about appearance or contents. Le Figaro notes that, when asked about her plans, she replied: “Je n'en sais rien, ... mais je sais bien ce que je ne ferais pas.” (Montclair 18) (I don't know anything about it, ... but I know what I would not do.) Raymond reportedly studied competing fashion periodicals to get a clear view of their imperfections, and, "grâce aux inventives ressources 
d'une diplomatie supérieure" (Montclair 18) (thanks to the inventive resources of superior diplomacy) gained a profound understanding of the needs of her subscribers. She is said to have edited La Mode illustrée with single-minded dedication, working ten hours a day, "n'allant que très peu dans le monde, jamais au théâtre, récompensée de cette austérité par les superbes résultats de ses efforts" (Montclair 18) (rarely going into society, never to the theater, rewarded for her austerity by the superb results of her efforts).

Whereas Aller and Raymond developed their magazines from scratch, the idea to establish an American weekly modelled on Der Bazar was not Mary Louise Booth's. It was publisher Fletcher Harper who first suggested it to his brothers, reportedly after seeing a German employee with a copy, and who travelled to Europe to arrange for clichés and early fashion proofs to be shipped over to New York on a regular basis (Harper 252, 255) (Figure 5). Yet, after he had hired Booth to execute the plan, she took sole charge, earning a handsome salary rising to $\$ 4000$ eventually (Stern 208): "For nineteen years Miss Booth has been habitually at the Bazar office from 9 A. M. to 4 P. M. daily," a colleague wrote towards the end of her career, "usually taking a light lunch in the office; permitting herself only a brief vacation at midsummer. Every line of manuscript in the paper, and its proof, is read by her. Every illustration is scrutinized by her" (Bolton 49). "Editorial work, like woman's work, is never done," Booth is quoted to have said, "and the planning of which it very largely consists goes on day and night without interruption." (Bolton, 46, 48-49) In all of this, "judicial capacity" was key: "It is not what the editor writes, but what he chooses for his paper, that makes or mars his success" (qtd. in Bolton 49).

A closer look at how the division of labor between publisher and editor came about is offered by the correspondence archive of A. W. Sijthoff, publisher of the Dutch Gracieuse. Now kept at Leiden University Library, the letters show Sijthoff recruiting the Weeveringh sisters through their brother, his accountant J. J. Weeveringh. The two women owned a needlework 
business in Haarlem, and had plenty of experience contributing to the well-established Dutch needlework magazine the Aglaja (1848-64). ${ }^{7}$ On 2 April 1862, Weeveringh informed Sijthoff that his sisters had agreed to edit the fashion and needlework section of the new magazine, proposing a salary of twenty guilders per issue, to be raised to twenty-five when the Gracieuse had successfully established itself in the market (Weeveringh): ${ }^{8}$

Zij rekenen ongeveer 12 pag. (Cendrillon-formaat) 's maands te behoeven en laten de rest aan de feuilletons. Hare 12 pag. verdeelen zij in handwerken, (kinder)modes, varia en correspondentie. Van tijdschriften wenschen zij voorlopig:

Cendrillon

Der Bazar

Lady's Newspaper

Lady's Companion

La mode illustrée with album

Journal des Dames et des Demoiselles

Aglaja

Maandschrift voor Dames

en de Bazaar (Weeveringh)

(They estimate they will need about 12 pages (Cendrillon format) per month and will leave the rest to the feuilletons. Their 12 pages will be divided into needlework, (children's) fashion, miscellaneous matter and correspondence. For the time being they would like the following magazines:

Cendrillon

Der Bazar

Lady's Newspaper

Lady's Companion 
La mode illustrée with album

Journal des Dames et des Demoiselles

Aglaja

Maandschrift voor Dames

and the Bazaar)

The list demonstrates the Weeveringh sisters' profound insight into the diversity and transnational dynamics of the fashion magazine market at the time. With titles in French, English, and German, it reaches out to all the major players in Western European fashion journalism. It includes established women's monthlies such as the British Lady's Companion, the Aglaja, and its French edition Cendrillon, traditional fashion journals such as the Journal des dames et demoiselles (the Belgian edition of Goubaud's influential Moniteur de la mode) as well as innovative illustrated fashion and dressmaking weeklies such as Der Bazar itself and La Mode illustrée.

Through their brother, the Weeveringh sisters also provided Sijthoff with detailed instructions about who to contract for the different types of contents. They preferred the fashion plates to be by Goubaud of Paris, because his were the prettiest and most affordable; the yellow dress paper patterns by the Dutch lithographers Emrik and Binger, because they always had the latest designs; the crochet patterns by the French haberdashery Maison Sajou, if the samples met their expectations; and the Berlin wool-work patterns by the German manufacturer Th. Wilh. Meister, because they were vastly superior to the French (Weeveringh). Sijthoff contacted Goubaud, who agreed to sell him the hand-colored fashion plates he produced for the Englishwoman's Domestic Magazine as part of the 1860 deal with Samuel Beeton (Goubaud). As a result, the plates were imported from France, but the inscription- "The Fashions. Expressly designed and prepared for the Gracieuse, Tijdschrift voor Jonge Dames"-was in English. No doubt to save costs, the black-and-white fashion and needlework illustrations were not ordered 
from Sajou or Meister, but reproduced from Der Bazar, which the sisters had also listed as a potential model. The layout was less sophisticated than that of the German original: small illustrations were inserted into the text instructions, larger ones were grouped and printed separately. Most likely, the Weeveringh sisters selected images from Der Bazar, sent instructions for reproduction to Emrik and Binger, and provided the Dutch translations of the accompanying textual material themselves.

This arrangement went smoothly for almost two years, until Schäfer found out that the Gracieuse contained unauthorized Bazar borrowings, and informed Sijthoff that he considered it a serious threat to the property value of his magazine. If Sijthoff was not prepared to pay for the clichés, Schäfer would undertake legal action and proceed with his own plans to issue a Dutch edition with a competing publisher (Schäfer). Sijthoff agreed, and a stream of letters followed negotiating the terms and conditions of the contract. Finally, it was decided that for a fixed annual sum, the Leipzig printer of Der Bazar, B. G. Teubner, would provide the pre-printed pages of the fashion and needlework issues without text (Figure 6). Publication frequency increased from monthly to two times a month to match that of the Bazar fashion issues. Copies of the original issues would be dispatched to the Weeveringh sisters as soon as they left the presses, so they could start preparing the translations to accompany the illustrations (Teubner) (Figures 7a and b).

\section{New directions}

Financial and legal considerations ultimately prevented Susanna Maria and Johanna Weeveringh from creating and maintaining the journal they had envisioned, but their initial confident response to Sijthoff testifies to the cultural capital that earned them a leading role in the set-up of the Gracieuse. By contrast, the editors of Harper's Bazar and La Mode illustrée were able to continue shaping their magazines in ways that went well beyond any preconceptions their publishers may 
have had as well as Schäfer's view of the periodicals as foreign editions of his Bazar. One of Mary Louise Booth's earliest and most conspicuous editorial decisions was the inclusion of a "New York Fashions" column alongside the material imported from Europe. On the one hand, she explained in a front-page mission statement in the first issue that Harper's Bazar had "perfected special arrangements with the leading European fashion journals, especially with the celebrated Bazar of Berlin, which supplies the fashions to the newspapers of Paris" ("Our Bazar" 2). American readers would thus be "sure of obtaining the genuine Paris fashions simultaneously with the Parisians themselves" ("Our Bazar" 2)—a feat, she pointed out, that no periodical on their side of the Atlantic had accomplished before. Booth may have had been alluding to journals such as Sarah Peterson's Lady's Friend, whose unauthorized reproductions of Bazar fashion illustrations were generally of poor quality and appeared with time lags of up to four months. On the other hand, the New York fashions column written by Booth's assistant Sallie Gore Shanks for almost three decades offered detailed descriptions of the latest local trends, often with prices and names of local suppliers. ${ }^{9}$ Booth's mission was not simply to bring Parisian fashion to New York but to turn New York into the "Paris of America" ("Our Bazar" 2). Under her editorship, Harper's Bazar positioned New York, and itself, as fashion gatekeepers to the nation, fostering the growth of a national sense of style in the post-Civil War era.

Like many Bazar "editions," Harper's Bazar was marketed as a family magazine with a special interest in fashion, yet Booth was one of the most outspoken about the editorial policies that this entailed. In an 1875 interview she told Charles Wingate that controversial topics had no place in its pages: "Care is taken to exclude everything of a political or sectarian nature, as well as all objectionable matter, and to make a paper which may be read aloud with pleasure and profit to the whole family." ("Mary L. Booth" 259) For that reason, she later wrote to a contributor, she considered it "inexpedient to advocate women's suffrage therein, either explicitly or implicitly" 
(qtd. in Harper 250). Booth herself, however, had been a women's rights advocate long before she became an editor, having served as secretary at women's rights conventions in 1855 and 1860 . She only refrained from public activism because she needed the steady income that Harper offered her.

That does not mean that Harper's Bazar eschewed women-specific issues altogether. For all Booth's insistence that the magazine was not a feminist publication, Paula Bernat Bennett makes compelling case for reading it as just that. Her argument rests on the numerous unsigned essays, possibly by the editor's own hand, exploring topics high on the agenda of the nascent feminist movement, such as female education and employment. Booth could broach these subjects not despite the focus on fashion, but rather because of it. In Bennett's words, she "recognized the potential in the high fashion magazine's generic position as trend-setter-its futuristic orientation-and exploited it from the start, using it as a cover for her advocacy of social and, in particular, gender reform" (226). Already in the first issue, a column wedged between Booth's mission statement and an article on suitable working attire sought to undermine the common assumption that female extravagance in dress was causing a decrease in marriage. The arguably less visible spending habits of young men in clubs and other closed settings, it argued, were equally if not more detrimental ("Expensive Matrimony" 2). By virtue of the magazine's miscellaneous format, Booth was able to merge issues of gender, social change, and fashion as signifiers of modernity.

Emmeline Raymond initially adopted a more conservative stance in La Mode illustrée. In one of the few early contributions in which she did address the question of women's work, she hastened to add that she had no intention of discussing it from a social point of view, even though the topic was "fort à la mode" [quite fashionable] at the time "et qu'en cette qualité une place puisse lui être accordée dans la Mode illustrée" (Raymond "Le travail" 390) (and as such could be granted a place in La Mode illustrée). Instead, she focused on the numerous letters she received from 
readers seeking remunerative employment, giving a rather bleak account of their reasons for doing so. With one pertinent example, she positioned herself on the opposite side of the argument advanced by Booth two years earlier: that of the spendthrift young lady, begging for a job that would allow her to pay off a 3,000 francs debt with her dressmaker within the next month. Such entreaties could not move Raymond, who emerged from the article as a stern observer of her own sex.

At the same time, Raymond herself in many ways embodied the emerging female professional, quickly rising to become a star of French fashion journalism and beyond. Unlike most of her colleagues at other Bazar "editions," she was a prominent presence in her own magazine. Her name appeared in the masthead of every front page and under many of the fashion contributions. Lengthy columns show her as a keen observer of the Parisian beau monde, offering readers personal observations and detailed descriptions of new garments spotted at high-society gatherings, in the streets, or in high-end shops. It was a job that Raymond took very seriously, and explicitly so. "Nous ne connaissons pas de personne plus occupée que nous-même" (We do not know of anyone busier than ourselves), she remarked in September 1860,

quand on nous enlève à ce bureau sur lequel nous écrivons à nos lectrices, quand nous sortons pour visiter Paris, nous ne voyons rien, par ce que nous devons nous occuper non de monuments, mais de toilettes et d'ouvrages de tous genres; si l'on nous interroge, nous ne répondons pas.... Tel est l'empire d'une idée fixe et d'une obligation que l'on veut remplir consciencieusement, que la robe de l'interlocutrice, son chapeau, son mantelet, nous absorbent aux dépens de sa conversation. (293-94)

(when we stand up from our desk at which we write to our readers, when we go out to visit Paris, we do not see anything, because we need to occupy ourselves not with the monuments but with outfits and works of all kinds; if we are asked a question, we do not respond... 
Such is the power of a fixed idea and an obligation that we want to fulfill conscientiously, that the dress of the interlocutor, her hat, her mantle, absorb us at the expense of her conversation.)

Building such a powerful editorial persona helped Raymond overcome a number of challenges related to the production and marketing of La Mode illustreé. Prospectuses show that she was well aware of the innovations that Der Bazar's practical hands-on approach could bring to French fashion journalism. They mention the wood engravings, large format and weekly frequency, which would allow La Mode illustrée, more than its monthly competitors, to keep readers informed of all the latest fashions prescribed by "le bon sens et le bon gout" ("Prospectus" [1860] 8) (common sense and good taste). Both were essential to Raymond's editorial project. On the one hand, she stressed the "importantes économies" (significant savings) that the patterns provided for women, who no longer needed to rely on "des mains étrangères" ("Prospectus" [n.d.] n.p.) (strangers' hands) to make clothes for themselves and their families. On the other, she preserved some of the sophistication of the traditional French fashion monthlies. From the beginning, $L a$ Mode illustrée appeared in four editions in different price ranges, the more expensive ones also offering hand-colored steel engravings by French artists such as Anaïs Toudouze and Héloïse Leloir. This was a marked deviation from Der Bazar, which following its 1857 make-over, for reasons of affordability, did not carry color plates until 1880s ("Vom 'Bazar"” 382).

Publisher Didot's deal with Schäfer, however, appears to have been less advantageous than Harper's and Sijthoff's, in the sense that La Mode illustrée often lagged significantly behind Der Bazar. A single issue contained illustrations and patterns that had been published in different Bazar numbers up to several weeks earlier. On 20 July 1861, for instance, La Mode illustrée featured a lace-edged taffeta necktie on its front page (Figure 8a) and a fashionable Zouave jacket on one of the inside pages. The jacket had previously appeared in Der Bazar on 23 May, the necktie on 23 
June (Figure 8b). Raymond could rely on the immediacy of the new "date-stamped" object to mask the time lag, but must have known that more was needed to make the journal a success. ${ }^{10}$ In order to establish itself in the market as French women's direct lifeline to Parisian fashion, any reliance on foreign material in the fashion department — and indeed the whole irony of a French magazine importing fashion material from Berlin—had to be glossed over.

Thus, the wood engravings in La Mode illustrée were never credited to Der Bazar, and Raymond's translations of the accompanying descriptions appeared anonymously, making them indistinguishable from unsigned original contributions. To appeal more directly to her French audience, Raymond often added the names and addresses of Paris shops where the depicted garments could be bought. For example, readers of the 27 April 1861 issue interested in the latest pardessus and mantillas worn by a group of women in a full-page landscape engraving were referred not only to the patterns in the supplement but also to Maison Leballeur at 74 rue Taitbout. The same illustration had appeared in Der Bazar four days earlier, with the patterns but without the coordinates of a local shop that could supply the items custom-made. Raymond's efforts to prevent all suspicion of secondariness become all the more obvious when compared to how she handled foreign fiction. La Mode illustrée was the first to introduce French readers to the popular German novelist E. Marlitt (pseudonym for Eugenie John), and Raymond made no secret of her mediating role as translator. She contributed numerous signed translations of Marlitt's works originally serialized in Die Gartenlaube and collected them in volumes afterwards. Several of her own novels, too, were explicit imitations from the German.

Raymond's editorial tactics worked, for in the subsequent two decades, she was able to bolster her leading position in fashion journalism on an international scale. Capitalizing on the one thing that Der Bazar, for all its expansionism, could not offer-actual proximity to Paris-she paved her own way to foreign audiences. In 1867, Der Bazar published a translation of her essay 
"La mode et la Parisienne," replete with bold claims about the self-confidence, good taste, and unerring intuition of Parisian women. ${ }^{11}$ Wondering why fashion was "mehr französisch, als russisch, deutsch oder englisch" (Raymond "Die Mode" 343) (more French than Russian, German, or English), Raymond argued that it could not do without the unique insight of the Parisienne into the complicated relationship between the finished fashion product and its diverse and often contradictory raw materials. Indeed, the whole essay is a declaration of Parisian women's world supremacy: "Sie haben sich das Universum unterworfen und regieren es nach den Eingebungen der wunderlichsten Laune. In ihren Händen liegt mehr, als das Leben, liegt die Schönheit aller Frauen der Erde" (343) (They have subjected the universe and govern it according to the dictates of the most whimsical mood. In their hands lies more than life, lies the beauty of all women on earth). At the same time, on a more personal level, it reads as an assertion of Raymond's indispensability as a cultural go-between for Der Bazar and its increasingly international readership as well as a fashion authority in her own right.

Raymond also extended her reach into the Spanish-speaking world. In 1861, Didot launched a Spanish edition of La Mode illustrée entitled La Moda illustrada, which was soon absorbed by the older Cádiz-based weekly La Moda (1842-61). As La Moda elegante, the newly amalgamated journal circulated in Spain and Portugal but also overseas in Spanish colonies such as Cuba, Puerto Rico, and the Philippines. Although Der Bazar claimed it as its Spanish edition, it was clearly a direct descendant of La Mode illustrée. It had a similar masthead designed and engraved by the same artists, Catenacci and Huyot, and its fashion plates and pattern sheets mentioned Didot's Paris address, 56 rue Jacob (Figure 9). Even if the agreement to import wood engravings was with Schäfer, the text descriptions were translated from the French. A typical example is that of the "Talma Clotilde," a design for a popular type of women's cloak, published in La Moda elegante for 19 July 1863 with characteristic back and front views. A few weeks earlier, 
the engraving had appeared under the same name in La Mode illustrée. In Der Bazar, however, the garment was referred to as "Talma Adelaide." ${ }^{2}$ Similarly, La Mode illustrée's "Costume de campagne" figures as "Trage [sic] para el campo" in La Moda elegante, as opposed to "PromenadeAnzug 'Adrienne'” in Der Bazar and "Adrienne Walking Dress" in Harper's Bazar. ${ }^{13}$ Sometimes, publication in La Mode illustrée preceded not only La Moda elegante but also Der Bazar itself. On 31 March 1863, for instance, Raymond discussed a piqué petticoat for sale at the Grands Magasins du Louvre, one of the most fashionable department stores in Paris. La Moda elegante included the engraving and translated description (without reference to the Louvre) in its 31 May issue; Der Bazar did not publish it until 15 June. ${ }^{14}$ This indicates that both periodicals imported at least some of their in-text fashion illustrations directly from France, and that, in the case of Der Bazar, the purported one-way relationship with La Mode illustrée went both ways.

Raymond's most visible presence in the foreign press were her signed fashion columns. The section entitled "Revista de modas" in La Moda elegante offered loose translations of the original French texts, usually stripped of their geographical markers. In 1869, she became the Paris fashion correspondent for Harper's Bazar. She held the post for more than two decades, but appeared only intermittently in its pages until 1871. The timing was no coincidence. The announcement of more regular contributions came only a month after the end of the FrancoPrussian war, which had "so long obstructed communications" ("Madame Raymond's Letter" 354). Harper's was proud to reconnect with Raymond, whose chief editorship of La Mode illustrée "render[ed] her oracular authority" (354) in that department. A few years later, Raymond also secured a spot in the mid-monthly supplement to Myra's Journal of Dress and Fashion (18751900), a London periodical edited by Matilda Browne and successor to the Englishwoman's Domestic Magazine in all but name. Fifteen years into La Mode illustrée's existence, Emmeline 
Raymond had established herself not only as the driving force behind her own journal but also as one of the pivotal—and certainly the most visible—figures in the Bazar network.

\section{Conclusion}

In 1887, the French bibliophile Henri Béraldi argued that the transformation of French fashion journalism had begun with La Mode illustrée. Under its influence, fashion periodicals "s'agrandissent, perdent leur aspect de revues littéraires; leur texte se remplit de bois intercalés, donnant les modèles de travaux à aiguille" (234) (expand, lose their appearance of literary journals; their text fills up with interspersed wood engravings showing needlework designs). Béraldi vaguely recalled that the magazine itself was indebted to "un journal de modes de Berlin, intitulé, je crois, Le Bazar" (234) (a Berlin fashion journal, entitled, I believe, The Bazar). More than a century later, hesitation has become silence. In her 2004 book-length study of the magazine, Raphaëlle RenkenDeshayes writes that La Mode illustrée "contribu[ait] à établir la reputation des Français en matière de mode" (69) (helped to establish the reputation of the French in matters of fashion), explaining that "c'[était] ... elle qui propos[ait] pour la première fois un descriptif détaillé des modèles sur la même page que les gravures non colorées" (40) (it was the first to propose a detailed description of the designs on the same page as the uncolored engravings). That Renken-Deshayes, like $\mathrm{La}$ Mode illustrée itself, makes no mention of Der Bazar is curiously at odds with how confidently and consistently La Mode illustrée was advertised in the German press as one of several foreign editions of Der Bazar. Clearly, the stakes for the two publications were so different that their relationship could not be mutually acknowledged.

These quotations illustrate the hypothesis that I have advanced in this article. Der Bazar and its foreign "Ausgaben" (editions) were interconnected in more complicated ways than the label suggests, and this was primarily due to the intellectual agency and cross-cultural vision of the 
women editors involved. Highly educated and often given considerable freedom by their publishers, these women forged their own networks and carved out their own spaces in the magazine market. The scope of my research has inevitably been influenced and limited by my own language skills. My focus has been on the German, French, English, and Dutch versions, with some attention to those in Spanish and Danish. More work would be needed to determine if the argument also holds for the Czech, Hungarian, and Russian Bazars and the Italian Novità, all of which appear to have been edited by women at some point. So far, the evidence suggests that, as cultural professionals, women editors were key mediators in the development of the illustrated fashion press and the fashion revolution that it sparked.

\section{Acknowledgements}

This work was supported by the European Research Council under the ERC Starting Grant agreement no. 639668.

\section{Notes}

[1] All translations are mine.

[2] The name of von Cosmar's second husband was Klein.

[3] According to the German socialist Ferdinand Lassalle, the 3.5 percent of the Prussian population earning an income of 400 to 1,000 thalers in the 1850 s were "in a comparatively comfortable position" (96).

[4] Nothing is known about Louise Fabé besides her name. The genealogical database Ancestry.com does list an unmarried woman by the name of Ida Marie Louise Fabé who died aged thirty-seven in 1870, the year in which Louise Fabé's name disappeared from the pages of Der Bazar. The Dutch newspaper Nieuwsblad voor den boekhandel also mentions a Miss Weigel working as fashion editor alongside Heigel in the early 1870s ("Gemengde berichten" 326).

[5] See, for example, the Ladies' Treasury, Mar. 1859, p. 89 and Der Bazar, 8 Feb. 1859, p. 41.

[6] Lotte Jensen writes about the Weeveringh sisters in her standard work on eighteenth- and nineteenth-century Dutch female journalists: "Over deze vrouwen is weinig bekend (zelfs geen voornamen)." (138) (Little is known about these women [not even their first names].) I identified them using the Dutch online genealogical database WieWasWie (https://www.wiewaswie.nl/). 
[7] The needlework business was advertised in the press and listed in contemporary Haarlem city directories, available online via the Noord-Hollands Archief newspaper repository (http://noordhollandsarchief.nl/).

[8] Amounting to an annual salary of 240 to 300 guilders (equivalent to about $£ 2,000$ to $£ 2,500$ today), this could have been little more than a modest supplement to the income from their needlework business. I used the relative value calculator on the website of the Dutch International Institute of Social History (IISH; http://www.iisg.nl/hpw/calculate.php).

[9] Shanks's tenure as fashion columnist began with the first issue and ended with her death in 1896 ("The Late Miss Shanks" 162).

[10] Cf. Margaret Beetham's description of the periodical as a "date-stamped commodity" (21) in her provocative essay "Towards a Theory of the Periodical as a Publishing Genre."

[11] The essay first appeared in Paris guide par les principaux écrivains et artistes de la France (1867).

[12] See La Moda elegante, 19 Jul. 1863, p. 229; La Mode illustrée, 25 May 1863, p. 165; Der Bazar, 1 Jun. 1863, p. 160.

[13] See Der Bazar, 15 May 1868, p. 153; La Mode illustrée, 17 May 1868, p. 157; Harper's Bazar, 28 May 1868, p. 473; La Moda elegante, 22 Jun. 1868, p. 185.

[14] See La Mode illustrée, 31 Mar. 1863, p. 97; La Moda elegante, 31 May 1863, p. 169; Der Bazar, 15 Jun. 1863, p. 177.

\section{Works Cited}

"14. (9. ausserordentliche) Versammlung des XV. Vereinjahres." Brandenburgia. Monatsblatt der Gesellschaft für Heimatkunde der Provinz Brandenburg zu Berlin, vol. 16, 1908, pp. 1-9.

“An unsere Abonnentinnen.” Der Bazar, 1 Dec. 1856, p. 339.

Beetham, Margaret. "Towards a Theory of the Periodical as a Publishing Genre.” Investigating Victorian Journalism, edited by Laurel Brake et al., Macmillan, 1990. 19-32.

Bennett, Paula Bernat. "Subtle Subversion: Mary Louise Booth and Harper's Bazar (1867-1889)." Blue Pencils and Hidden Hands: Women Editing Periodicals, 1830-1910, edited by Sharon M. Harris and Ellen Gruber Garvey. Northeastern UP, 2004. 225-43.

Béraldi, Henri. Les graveurs du XIXe siècle: guide de l'amateur d'estampes modernes, vol. 6, Conquet, 1887.

Best, Kate Nelson. "Text and Image in Fashion Periodicals of the Second French Empire." Text and Image in Modern European Culture, edited by Natasha Grigorian et al., Purdue UP, 2012. 101-14.

Boehn, Max von. “70 Jahre 'Bazar,' 1854-1924.” 70 Jahre deutsche Mode: Zur Geschichte einer deutschen Modezeitschrift. Bazar-Actien-Ges., 1925. n.p.

Bolton, Sarah K. Successful Women. Lothrop, 1888. 
Brümmer, Franz. Lexikon der deutschen Dichter und Prosaisten vom Beginn des 19. Jahrhunderts bis zur Gegenwart, vol. 1, Reclam, 1913.

Clark, Caryl. "Reading and Listening: Viennese Frauenzimmer Journals and the Sociocultural Context of Mozartean Opera Buffa.” The Musical Quarterly, vol. 87, no. 1, 2004, pp. 140-75.

"Der Bazar.” Wöchentliche Anzeigen für das Fürstenthum Ratzeburg, 11 Dec. 1863, n.p.

"Der Bazar." Supplement to Illustrirte Zeitung, 29 Mar. 1873, p. 241.

"Ein Buchhändler." Erheiterungen, 22 Dec. 1854, p. 1220.

Emery, Joy Spanabel. A History of the Paper Pattern Industry. Bloomsbury, 2014.

"Expensive Matrimony." Harper's Bazar, 2 Nov. 1867, p. 2.

"Frauen-Industrie.” Regensburger Zeitung Unterhaltungsblatt, no. 4, 1861, pp. 3-4.

"Freifrau von Lipperheide, Frieda." Biographisches Jahrbuch und Deutscher Nekrolog, vol. 1, edited by Anton Bettelheim., Reimer, 1897. 137-39.

“Gemengde berichten.” Nieuwsblad voor den boekhandel, 19 Sept. 1871, p. 326.

Goubaud, Adolphe, to A. W. Sijthoff. 16 and 30 May 1862. SYT A 1862, nos. 38-39. Leiden University Library, Leiden.

Grølsted, Esther. “Laura Aller og Nordisk Mønster-Tidende.” Dragtjournalen, vol. 9, no. 13, 2015, pp. 17 23.

Harper, J. Henry. The House of Harper. A Century of Publishing in Franklin Square. Harper, 1912.

"Herr Abington." Indiana Tribüne, 23 Apr. 1884, p. 2.

Hughes, Kathryn. The Short Life and Long Times of Mrs. Beeton. Knopf, 2006.

Jensen, Lotte. "Bij uitsluiting voor de vrouwelijke sekse geschikt." Vrouwentijdschriften en journalistes in Nederland in de achttiende en negentiende eeuw. Verloren, 2001.

Kaehler, Siegfried A. Beiträge zur Chronik der Familie Kähler. n.p., 1869.

Lassalle, Ferdinand. "Open Letter to the National Labor Association of Germany." German Essays on Socialism in the Nineteenth Century: Theory, History, and Political Organization, 1844-1914, edited by Frank Mecklenburg and Manfred Stassen, Continuum, 1990. 79-102.

“The Late Miss Shanks.” Harper's Bazar, 29 Feb. 1896, p. 162.

“Madame Raymond's Letter.” Harper's Bazar, 10 Jun. 1871, p. 354.

"Mary L. Booth, Editor of 'Harper's Bazar'." Views and Interviews on Journalism, edited by Charles Wingate. Patterson, 1875. 253-59.

Montclair. "Silhouettes féminines. Mme Emmeline Raymond." Figaro. Supplément littéraire du dimanche, 1 Feb. 1890, p. 18.

Morgenstern, Lina. Die Frauen des 19. Jahrhunderts: Biographische und Culturhistorische Zeit- und Charactergemälde, vol. 3, Verlag der Deutschen Hausfrauen-Zeitung, 1891. 
“Our Bazar.” Harper's Bazar, 2 Nov. 1867, p. 2.

"Prospectus." Didot, n.d.

Raymond, Emmeline. "Prospectus." La Mode illustrée, 1 Jan. 1860, p. 8.

---. "Modes." La Mode illustrée, 8 Sept. 1860, pp. 293-94.

---. "Die Mode und die Pariserin." Der Bazar, 8 Nov. 1867, p. 343.

---. "Le travail des femmes." La Mode illustrée, 5 Dec. 1869, pp. 390-91.

Renken-Deshayes, Raphä̈lle. "Miroir, mon beau miroir..." L'identité féminine définie par un journal de mode La Mode illustrée: journal de la famille. Editions Alphil, 2004.

Schäfer, Louis, to A. W. Sijthoff. 20 Sept. 1862, SYT A 1862, no. 158. Leiden University Library, Leiden.

Schreve, Gustav. Phrenologische Frauenbilder: Dresdens Schriftstellerinnen der Gegenwart. Schöpff, 1865. 340-50.

Spofford, Harriet Prescott. "Mary Louise Booth.” Harper's Bazar, 30 Mar. 1889, 232.

Stern, Madeleine B. "Booth, Mary Louise." Notable American Women, 1607-1950: A Biographical Dictionary, vol. 1, edited by Edward T. James et al., Harvard UP, 1971. 207-08.

Teubner, B. G., to A. W. Sijthoff. 11 Nov. 1864. SYT A 1864, no. 166. Leiden University Library, Leiden. “Vom 'Bazar,' ein Gedenkblatt für unsere Leserinnen und Leser.” Der Bazar, 23 Dec. 1868, pp. 381-83.

Weeveringh, J. J., to A. W. Sijthoff. 2 Apr. 1862. SYT A 1862, no. 59. Leiden University Library, Leiden.

“Zum Beginn des neuen Jahrgangs.” Der Bazar, 1 Jan. 1869, p. 1.

\section{Figure captions}

Figure 1 Title page of a fashion issue after the make-over, Der Bazar, 9 Jan. 1858. University and State Library Düsseldorf, urn:nbn:de:hbz:061:1-31458.

Figure 2 Example of a page from an early Bazar issue, before the make-over, 15 Aug. 1856. Bayerische Staatsbibliothek.

Figure 3 Example of a double page from Der Bazar after the make-over, Der Bazar, 8 Oct. 1859. University and State Library Düsseldorf, urn:nbn:de:hbz:061:1-31458.

Figure 4 Double-page engraving depicting the magazine's production process, Der Bazar, 23 Dec. 1868. Bayerische Staatsbibliothek.

Figure 5 Title page of the first issue of Harper's Bazar, 2 Nov. 1867. Albert R. Mann Library, Cornell University.

Figure 6 Example of a double Bazar page with the illustrations only, enclosed in a letter from Schäfer to Sijthoff, 26 Jun. 1863. Leiden University Library.

Figure 7a Page from Der Bazar, 15 Dec. 1864. University and State Library Düsseldorf, urn:nbn:de:hbz:061:1-31458. 
Figure 7b The same page in the Gracieuse, with Dutch translations, 15 Dec. 1864. The Hague Municipal Museum.

Figure 8a "Nœud de cravate," La Mode illustrée, 20 Jul. 1861, [p. 233]. Bunka Gakuen Library, Tokyo.

Figure 8b "Cravattenschleife," Der Bazar, 23 Jun. 1861, p. 192. University and State Library Düsseldorf, urn:nbn:de:hbz:061:1-31458.

Figure 9 Title page of the first issue of La Moda elegante, 3 Jan. 1861. National Library of Spain. 